\title{
8-Nitroguanine as a potential biomarker for progression of malignant fibrous histiocytoma, a model of inflammation-related cancer
}

\author{
YOKO HOKI ${ }^{1}$, MARIKO MURATA ${ }^{2}$, YUSUKE HIRAKU $^{2}$, NING MA $^{3}$, \\ AKIHIKO MATSUMINE $^{1}$, ATSUMASA UCHIDA ${ }^{1}$ and SHOSUKE KAWANISHI ${ }^{2,4}$ \\ Departments of ${ }^{1}$ Orthopaedic Surgery, ${ }^{2}$ Environmental and Molecular Medicine, and ${ }^{3}$ Anatomy, Mie University \\ Graduate School of Medicine, Tsu, Mie 514-8507; ${ }^{4}$ Faculty of Health Science, Suzuka University \\ of Medical Science, 1001-1 Kishioka, Suzuka, Mie 510-0293, Japan
}

Received March 28, 2007; Accepted June 25, 2007

\begin{abstract}
Chronic inflammation is a critical component of carcinogenesis and tumor progression. Reactive nitrogen and oxygen species generated by inflammatory cells form mutagenic DNA lesions, such as 8-nitroguanine, which may play an integral role in inflammation-related carcinogenesis. Hypoxiainducible factor (HIF)- $1 \alpha$ has been established as a prognostic biomarker in various tumors, including malignant fibrous histiocytoma (MFH). The aim of this study was to evaluate the impact of 8-nitroguanine formation and HIF-1 $\alpha$ expression on the prognosis of patients with inflammation-related cancer. Immunohistochemical analyses were employed to examine the distribution of 8-nitroguanine and HIF-1 $\alpha$, using clinical specimens from 36 patients with $\mathrm{MFH}$ as a model of inflammation-related cancer. 8-Nitroguanine formation was predominately observed in the nuclei of tumor cells and inflammatory cells in tumor tissues, while HIF-1 $\alpha$ was expressed in the cytoplasm and nuclei of tumor cells. Little or no immunoreactivity of 8-nitroguanine and HIF-1 $\alpha$ was observed in adjacent non-tumor tissues. Significantly higher levels of both 8-nitroguanine and HIF-1 $\alpha$ were observed in the tissue specimens of deceased patients than in those of living subjects. Survival curves analyzed by the KaplanMeier method differed significantly between the high- and low-staining groups of 8 -nitroguanine $(\mathrm{p}=0.00003)$ as well as HIF- $1 \alpha(p=0.01104)$. These results suggest a significant role of the pathway of iNOS-dependent 8-nitroguanine formation via HIF- $1 \alpha$ and NF- $\kappa$ B on the progression of inflammation-
\end{abstract}

Correspondence to: Professor Shosuke Kawanishi, Faculty of Health Science, Suzuka University of Medical Science, 1001-1 Kishioka, Suzuka, Mie 510-0293, Japan

E-mail: kawanisi@suzuka-u.ac.jp

Key words: 8-nitroguanine, hypoxia-inducible factor-1 $\alpha$, malignant fibrous histiocytoma, inflammation, hypoxia, DNA damage, carcinogenesis, tumor progression, prognosis related cancer. In conclusion, 8-nitroguanine is an excellent candidate prognostic and predictive biomarker together with HIF- $1 \alpha$ in inflammation-related tumor progression.

\section{Introduction}

Inflammation is a critical component of carcinogenesis and tumor progression (1). Many malignancies arise from inflammatory sites, and chronic inflammation contributes to the development of various cancers $(1,2)$. In cases of chronic inflammation, reactive nitrogen species (RNS) and reactive oxygen species (ROS) are generated by inflammatory cells and the epithelium $(3,4)$. RNS mediate 8-nitroguanine formation, a marker of nitrative DNA damage (5). 8-Nitroguanine has been reported to be formed in association with inflammationrelated carcinogenesis (6-9), including malignant fibrous histiocytoma (MFH), as reported previously (10). MFH is the most commonly diagnosed soft-tissue sarcoma in adults $(11,12)$ and has a poor prognosis $(13,14)$. Several studies have shown that hypoxia-inducible factor (HIF)- $1 \alpha$ could be a biomarker of a poor prognosis in various cancers (15-17), including soft-tissue sarcomas (18). The HIF-1 $\alpha$ protein supports the adaptation of human cancer cells to hypoxia under tumor growth.

This study investigates 8-nitroguanine formation and HIF- $1 \alpha$ expression in surgical specimens of MFH patients using immunohistochemical staining procedures. We evaluated the impact of 8-nitroguanine formation and HIF- $1 \alpha$ expression on prognosis, and examined their usefulness as potential biomarkers.

\section{Materials and methods}

Tissue preparation and clinicopathological analysis. Thirtysix MFH patients who underwent an open biopsy or a surgical resection from 1989 to 2004 at the Department of Orthopaedic Surgery, Mie University Graduate School of Medicine, Japan, participated in this study, which was approved by the Ethics Committee of Mie University Graduate School of Medicine. All patients were diagnosed by well-trained pathologists, according to the Enzinger and Weiss classification (19). The 


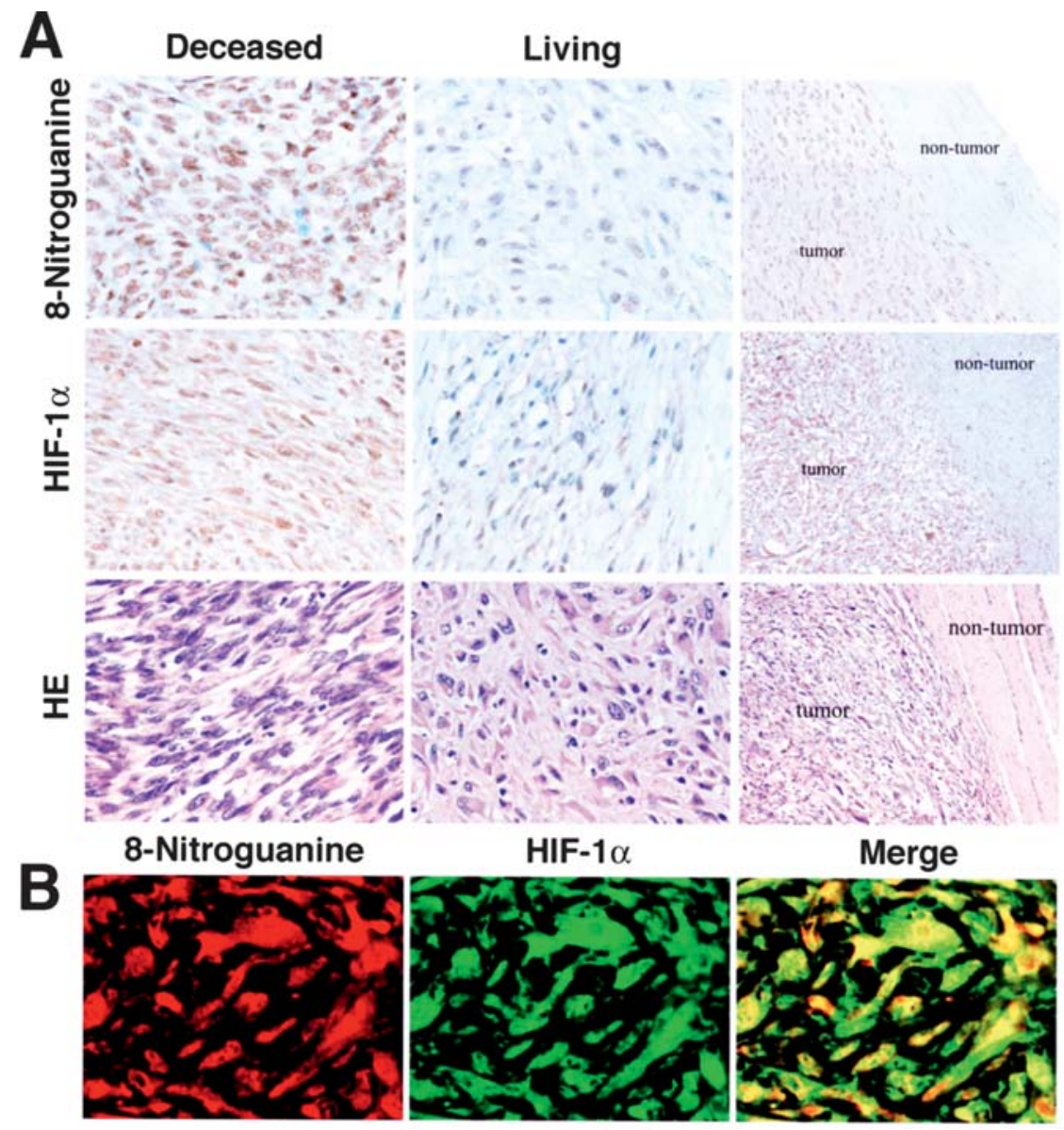

Figure 1. 8-Nitroguanine formation and HIF-1 $\alpha$ expression in MFH patients. (A) 8-Nitroguanine formation and HIF-1 $\alpha$ expression by immunohistochemical staining using the LSAB method and hematoxylin and eosin staining. Both are observed in the nuclei of tumor cells and inflammatory cells within MFH tissue specimens. The immunoreactivity of 8-nitroguanine and HIF-1 $\alpha$ is found to be greater in deceased patients than in living subjects. Little or no immunoreactivity of 8-nitroguanine and HIF-1 $\alpha$ is observed in adjacent non-tumor tissues. Magnification, $\mathrm{x} 400$ (left and center columns) and x100 (right column). (B) The detection of colocalization of 8-nitroguanine with HIF-1 $\alpha$ by double immunofluorescence staining. 8-Nitroguanine and HIF-1 $\alpha$ are colocalized in the same tumor cells. Magnification, x880.

patients comprised 20 men and 16 women ranging in age from 27 to 85 years (mean \pm SD, $63.0 \pm 13.0$ years). Survival data were available for all patients. The duration of the followup ranged from 4 to 213 months (median, 63 months). The tumor samples were classified as Stage IIa (2 patients), Stage IIb ( 3 patients), Stage III (25 patients) and Stage IV (6 patients) at the time of the original diagnosis. The International Union Against Cancer TNM classification and the staging system by the American Joint Committee on Cancer (AJCC) were used for tumor assessment (20). One of 2 patients in Stage IIa, none of 3 patients in Stage IIb, 9 of 25 patients in Stage III, and all of 6 patients in Stage IV died. Thirty-four tumors measured $5-22 \mathrm{~cm}$ in diameter, while the other 2 tumors were $<5 \mathrm{~cm}$ in diameter (mean $\pm \mathrm{SD}, 11.15 \pm 4.48 \mathrm{~cm}$ in diameter).

Immunohistochemical analysis for 8-nitroguanine and HIF-1 $\alpha$. Immunohistochemical staining was performed using the labeled streptavidin-biotin (LSAB) method. The sections were deparaffinized and automated immunohistochemistry was performed with a NexES IHC (Ventana Medical Systems, Inc., Tucson, AZ, USA) as previously described (10). The rabbit polyclonal anti-8-nitroguanine antibody produced by this laboratory (21) was used as the primary antibody at a concentration of $2 \mu \mathrm{g} / \mathrm{ml}$. The mouse monoclonal anti-HIF- $1 \alpha$ antibody (Calbiochem-Novabiochem, Darmstadt, Germany) was diluted at 1:500. As secondary antibodies, anti-mouse IgG and anti-rabbit IgG antibodies (Ventana Medical Systems, Inc.) were used. The Lumina Vision version 1.11 software program (Mitani Shoji Co., Fukui, Japan) for performing morphometric analyses was used to measure the staining rates of 8-nitroguanine and HIF-1 $\alpha$.

To examine the colocalization of 8-nitroguanine formation and HIF- $1 \alpha$ expression, a double immunofluorescence technique was used, as described previously (10). The stained sections were examined under a fluorescence microscope (BX50F-3, Olympus Optical Co., Ltd., Japan).

Histopathological staining. A histopathological study was performed, following the standard method, using hematoxylin and eosin staining in paraffin sections .

Statistical analysis. The patients were categorized into five subgroups according to the staining rates $(<7.5,7.5-15.0$, $15.0-22.5,22.5-30.0$ and $>30.0 \%$ ) and evaluated as described above. Then, statistical differences of the immunoreactivities between deceased and living patients were analyzed by $\chi^{2}$-test. Survival between the two subgroups, high-grade (staining rates, $\geq 15 \%)$ and low-grade $(<15 \%)$, was compared using the 
Table I. Differences in the immunohistochemical staining of 8-nitroguanine and HIF- $1 \alpha$ between deceased and living patients with malignant fibrous histiocytoma.

\begin{tabular}{|c|c|c|c|c|}
\hline \multirow[b]{2}{*}{$\begin{array}{l}\text { Staining } \\
\text { rate }(\%)\end{array}$} & \multicolumn{2}{|c|}{ 8-Nitroguanine } & \multicolumn{2}{|c|}{ HIF-1 $\alpha$} \\
\hline & $\begin{array}{l}\text { Living } \\
\text { patients } \\
(\mathrm{n}=20)\end{array}$ & $\begin{array}{c}\text { Deceased } \\
\text { patients } \\
(n=16)\end{array}$ & $\begin{array}{l}\text { Living } \\
\text { patients } \\
(\mathrm{n}=20)\end{array}$ & $\begin{array}{c}\text { Deceased } \\
\text { patients } \\
(n=16)\end{array}$ \\
\hline $0.0-7.5$ & $9(45.00)^{\mathrm{a}}$ & $1 \quad(6.25)$ & $11(55.00)$ & $3(18.75)$ \\
\hline $7.5-15.0$ & $9(45.00)$ & $2(12.50)$ & $5(25.00)$ & $2(12.50)$ \\
\hline $15.0-22.5$ & $2(10.00)$ & $9(56.25)$ & $4(20.00)$ & $4(25.00)$ \\
\hline $22.5-30.0$ & $0 \quad(0.00)$ & $2(12.50)$ & $0 \quad(0.00)$ & $5(31.25)$ \\
\hline$>30.0$ & $0 \quad(0.00)$ & $2(12.50)$ & $\begin{array}{ll}0 & (0.00)\end{array}$ & $2(12.50)$ \\
\hline P-value & \multicolumn{2}{|c|}{0.00075} & \multicolumn{2}{|c|}{0.01359} \\
\hline
\end{tabular}

${ }^{a}$ No. of patients (\%).

life-table method of Kaplan-Meier, and then statistically analyzed by the generalized Wilcoxon test. P-values of $<0.05$ were considered to be statistically significant.

\section{Results}

Histopathological findings, 8-nitroguanine formation and HIF-1 a expression in tumor tissues of MFH patients. Fig. $1 \mathrm{~A}$ shows the histopathological observations of 8-nitroguanine formation and HIF- $1 \alpha$ expression in the specimens from MFH patients. 8-Nitroguanine was predominately observed in the nuclei of the tumor cells and inflammatory cells within the MFH tissue specimens. HIF-1 $\alpha$ expression was detected in the cytoplasm and nuclei of tumor cells. Little or no immunoreactivity of 8 -nitroguanine and HIF- $1 \alpha$ was observed in adjacent non-tumor tissues (Fig. 1A, right). Significantly higher levels of both 8-nitroguanine and HIF-1 $\alpha$ were observed in the tissue specimens of deceased patients than in those of living subjects (Fig. 1A and Table I).

Fig. 1B shows the colocalization of 8-nitroguanine (red) with HIF-1 $\alpha$ (green) visualized using a double immunofluorescence technique. The expression of HIF-1 $\alpha$ was strongly detected in the nucleus of tumor cells and was co-localized with 8-nitroguanine (Fig. 1B). In addition, immunoreactivities of 8-nitroguanine and HIF-1 $\alpha$ were observed in giant cells and inflammatory cells from MFH tissues (data not shown).

Comparison of the immunoreactivity of 8-nitroguanine and $H I F-1 \alpha$, in relation to prognosis. Table I demonstrates that the immunoreactivity of 8-nitroguanine was significantly stronger in the tumor tissues of deceased patients than in those of living patients. The generalized Wilcoxon test, using the Kaplan-Meier method, was used to evaluate the association of 8-nitroguanine and HIF-1 $\alpha$ with the prognosis of MFH patients (Fig. 2). MFH patients with high-grade staining $(\geq 15 \%)$ of 8 -nitroguanine ( $\mathrm{p}=0.00003)$ had a significantly shorter survival than those with low-grade staining $(<15 \%)$
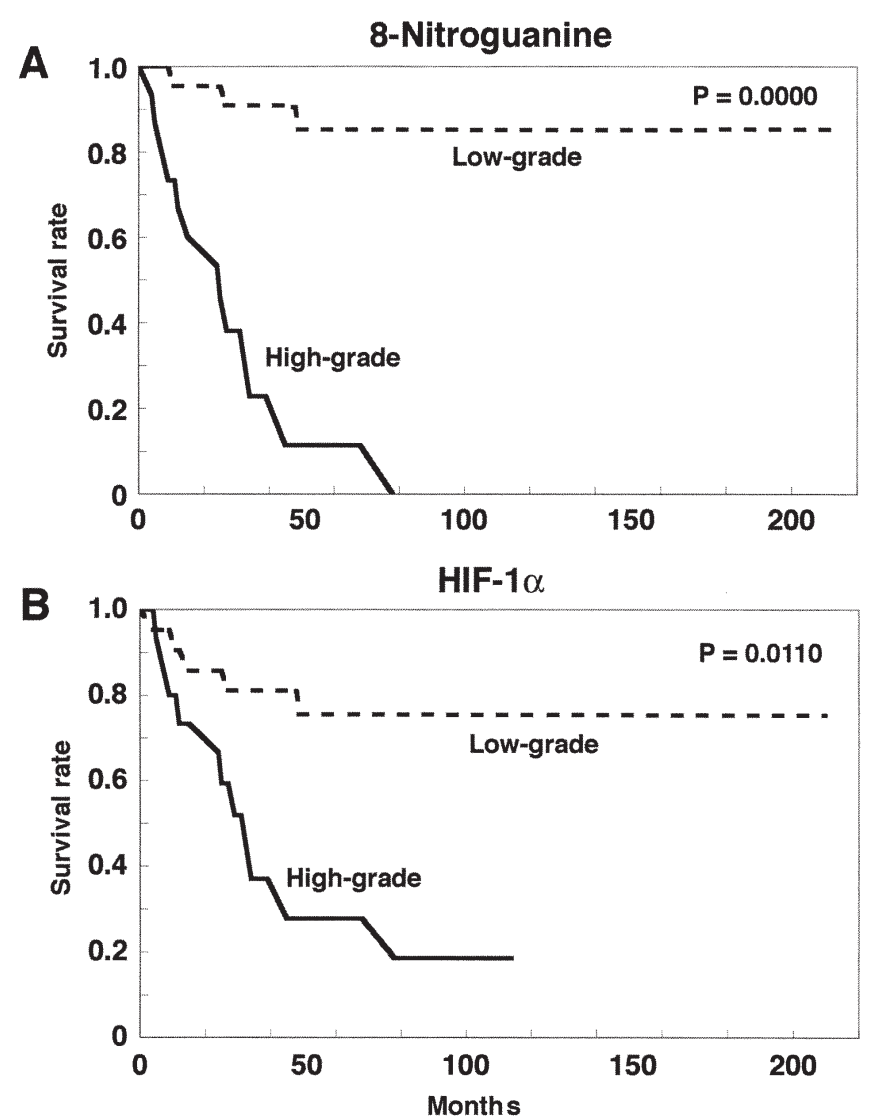

Figure 2. The survival curves of MFH patients as determined by the KaplanMeier method. Solid lines, patients with high-grade staining ( $\geq 15 \%$ detected by Lumina Vision) of 8-nitroguanine (A) or HIF-1 $\alpha$ (B). Broken lines, patients with low-grade staining $(<15 \%)$.

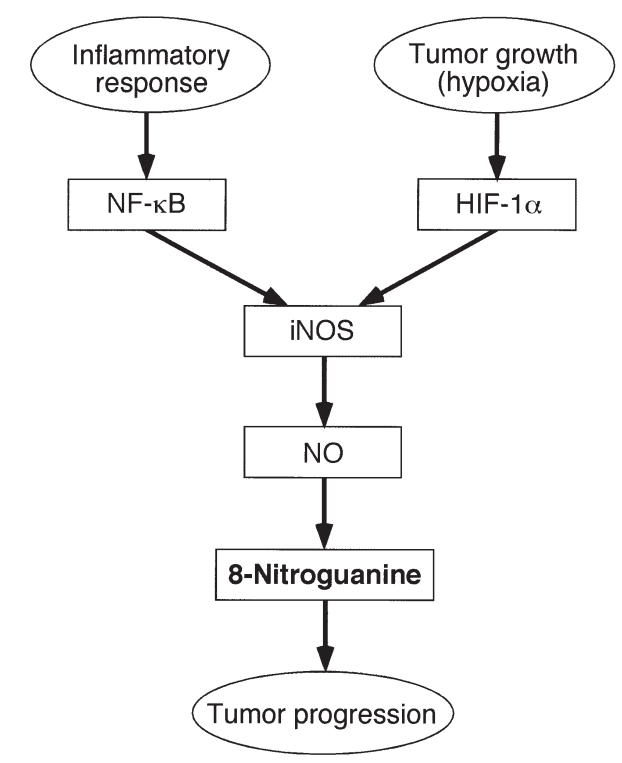

Figure 3. The proposed mechanism of inflammation and hypoxia-induced 8-nitroguanine formation leading to tumor progression.

(Fig. 2A). Meanwhile, patients with high-grade staining of HIF- $1 \alpha(p=0.01104)$ also exhibited a significantly poor prognosis in comparison to those with low-grade staining (Fig. 2B). 


\section{Discussion}

The accumulation of 8-nitroguanine formation and HIF-1 $\alpha$ expression was examined in surgical specimens of MFH patients and was found to correlate with the prognosis of inflammation-related cancer. 8-Nitroguanine was clearly colocalized with HIF- $1 \alpha$ in the nuclei of tumor cells, giant cells and inflammatory cells in MFH tissues. There was a significant difference in the immunoreactivity of 8-nitroguanine $(\mathrm{p}=0.00075)$ between the deceased and living patients, with HIF- $1 \alpha(p=0.01359)$ exhibiting similar differences. The survival curves of MFH patients, according to the KaplanMeier method, differed more clearly between the groups distinguished by 8 -nitroguanine $(\mathrm{p}=0.00003)$ rather than by HIF-1 $\alpha(\mathrm{p}=0.01104)$.

Intratumoral hypoxia induces a rapid increase of HIF-1 protein $(22,23)$, a heterodimer consisting of $\alpha$ and $\beta$ subunits, in tumor cells. HIF-1 $\alpha$ expression is related to cellular oxygen status (24). Under hypoxic conditions, the degradation of HIF- $1 \alpha$ is suppressed and, subsequently, HIF- $1 \alpha$ dimerizes with HIF-1ß in the nucleus, thus promoting the expression of numerous target genes (18). iNOS is one of the known HIF-1inducible proteins. Previous studies have shown that HIF-1 $\alpha$ is expressed in the nuclei of tumor cells, suggesting that HIF- $1 \alpha$ is activated in MFH tumor tissues under hypoxic conditions. HIF-1 $\alpha$ expression in tumor cells correlated with iNOS expression in MFH tissues $(\mathrm{R}=0.58923, \mathrm{p}=0.00194)$, and double immunofluorescence revealed that 8-nitroguanine and HIF- $1 \alpha$ were colocalized in cancerous tissues. In addition, our previous findings demonstrated that 8-nitroguanine was formed via HIF-1 $\alpha$-dependent iNOS expression in relation to the progression of cholangiocarcinoma (25). It therefore appears likely that tumor hypoxia induces HIF-1 $\alpha$ expression, which mediates iNOS expression and results in 8-nitroguanine formation.

$\mathrm{NF}-\kappa \mathrm{B}$ is considered to be a key player in inflammation since it regulates the expression of various genes involved in controlling inflammatory response, including iNOS expression (26). NF- $\mathrm{kB}$ functions as a tumor promoter in inflammationassociated cancers (27). Previous studies have reported that 8 -nitroguanine is colocalized with iNOS and NF-кB in tumor cells of MFH patients (10). Therefore, 8-nitroguanine can be formed through iNOS expression, mediated by $\mathrm{NF}-\kappa \mathrm{B}$ activation.

8-Nitroguanine is formed under inflammatory conditions and plays a substantial role in inflammation-related carcinogenesis, including MFH (10). Chemically unstable 8-nitroguanine formed in DNA can be spontaneously released, thereby causing the formation of an apurinic site (5). This can form a base-pair with adenine during DNA synthesis, resulting in $\mathrm{G} \rightarrow \mathrm{T}$ transversions (28). Translesion DNA synthesis past an apurinic site mediated by DNA polymerase $\zeta$ may contribute to point mutations (29). As a result, inflammatory responses may participate in tumor progression through the formation of mutagenic DNA lesions, such as 8nitroguanine.

Based on these findings and previous research, a mechanism of tumor progression by hypoxia and inflammation can be proposed, as illustrated in Fig. 3. One pathway is initiated by 'hypoxia in tumor growth', where HIF-1 $\alpha$ triggers the iNOS expression, and then 8-nitroguanine formation facilitates tumor progression. The other pathway starts with the 'inflammatory response', where NF- $\mathrm{BB}$ is activated by a variety of stimuli including inflammatory cytokines, and iNOS is expressed. These pathways converge into a common pathway, namely iNOS-dependent 8-nitroguanine formation. Consequently 8-nitroguanine, together with HIF$1 \alpha$, is considered to be an excellent candidate prognostic and predictive biomarker in inflammation-related cancer, including MFH.

\section{Acknowledgements}

This study was supported by Grants-in-Aid for Scientific Research from the Ministry of Education, Culture, Sports, Science and Technology and the Ministry of Health, Labour and Welfare of Japan.

\section{References}

1. Coussens LM and Werb Z: Inflammation and cancer. Nature 420: 860-867, 2002.

2. Balkwill $\mathrm{F}$ and Mantovani A: Inflammation and cancer: back to Virchow? Lancet 357: 539-545, 2001.

3. Hussain SP, Hofseth LJ and Harris CC: Radical causes of cancer. Nat Rev Cancer 3: 276-285, 2003.

4. Ohshima H, Tatemichi $M$ and Sawa T: Chemical basis of inflammation-induced carcinogenesis. Arch Biochem Biophys 417: 3-11, 2003.

5. Yermilov V, Rubio J, Becchi M, Friesen MD, Pignatelli B and Ohshima H: Formation of 8-nitroguanine by the reaction of guanine with peroxynitrite in vitro. Carcinogenesis 16: 2045-2050, 1995.

6. Kawanishi S, Hiraku Y, Pinlaor S and Ma N: Oxidative and nitrative DNA damage in animals and patients with inflammatory diseases in relation to inflammation-related carcinogenesis. Biol Chem 387: 365-372, 2006.

7. Kawanishi S and Hiraku Y: Oxidative and nitrative DNA damage as biomarker for carcinogenesis with special reference to inflammation. Antioxid Redox Signal 8: 1047-1058, 2006.

8. Ma N, Tagawa T, Hiraku Y, Murata M, Ding X and Kawanishi S: 8-Nitroguanine formation in oral leukoplakia, a premalignant lesion. Nitric Oxide 14: 137-143, 2006.

9. Pinlaor S, Ma N, Hiraku Y, Yongvanit P, Semba R, Oikawa S, Murata M, Sripa B, Sithithaworn P and Kawanishi S: Repeated infection with Opisthorchis viverrini induces accumulation of 8-nitroguanine and 8-oxo-7,8-dihydro-2'-deoxyguanine in the bile duct of hamsters via inducible nitric oxide synthase. Carcinogenesis 25: 1535-1542, 2004.

10. Hoki Y, Hiraku Y, Ma N, Murata M, Matsumine A, Nagahama M, Shintani K, Uchida A and Kawanishi S: iNOSdependent DNA damage in patients with malignant fibrous histiocytoma in relation to prognosis. Cancer Sci 98: 163-168, 2007.

11. Jemal A, Tiwari RC, Murray T, Ghafoor A, Samuels A, Ward E, Feuer EJ and Thun MJ: Cancer statistics, 2004. CA Cancer J Clin 54: 8-29, 2004.

12. Weiss SW and Enzinger FM: Malignant fibrous histiocytoma: an analysis of 200 cases. Cancer 41: 2250-2266, 1978.

13. Belal A, Kandil A, Allam A, Khafaga Y, El-Husseiny G, ElEnbaby A, Memon M, Younge D, Moreau P, Gray A and Schultz H: Malignant fibrous histiocytoma: a retrospective study of 109 cases. Am J Clin Oncol 25: 16-22, 2002.

14. Randall RL, Albritton KH, Ferney BJ and Layfield L: Malignant fibrous histiocytoma of soft tissue: an abandoned diagnosis. Am J Orthop 33: 602-608, 2004.

15. Hockel M, Schlenger K, Aral B, Mitze M, Schaffer U and Vaupel P: Association between tumor hypoxia and malignant progression in advanced cancer of the uterine cervix. Cancer Res 56: 4509-4515, 1996.

16. Schindl M, Schoppmann SF, Samonigg H, Hausmaninger H, Kwasny W, Gnant M, Jakesz R, Kubista E, Birner P and Oberhuber G: Overexpression of hypoxia-inducible factor $1 \alpha$ is associated with an unfavorable prognosis in lymph nodepositive breast cancer. Clin Cancer Res 8: 1831-1837, 2002. 
17. Birner P, Gatterbauer B, Oberhuber G, Schindl M, Rossler K, Prodinger A, Budka $\mathrm{H}$ and Hainfellner JA: Expression of hypoxia-inducible factor- $1 \alpha$ in oligodendrogliomas: its impact on prognosis and on neoangiogenesis. Cancer 92: 165-171, 2001.

18. Shintani K, Matsumine A, Kusuzaki K, Matsubara T, Satonaka $\mathrm{H}$, Wakabayashi T, Hoki Y and Uchida A: Expression of hypoxia-inducible factor (HIF)- $1 \alpha$ as a biomarker of outcome in soft-tissue sarcomas. Virchows Arch 449: 673-681, 2006.

19. Weiss SW and Goldbum JR: Enzinger and Weiss's Soft Tissue Tumors. 4th edition. Mosby Co., St. Louis, 2002.

20. Greene FL, Page DL, Fleming ID, Fritz A, Balch CM, Haller DG and Morrow M (eds): AJCC Cancer Staging Manual. Springer, Berlin, 2002.

21. Pinlaor S, Hiraku Y, Ma N, Yongvanit P, Semba R, Oikawa S, Murata M, Sripa B, Sithithaworn P and Kawanishi S: Mechanism of NO-mediated oxidative and nitrative DNA damage in hamsters infected with Opisthorchis viverrini: a model of inflammation-mediated carcinogenesis. Nitric Oxide 11: 175-183, 2004.

22. Harris AL: Hypoxia - a key regulatory factor in tumour growth. Nat Rev Cancer 2: 38-47, 2002.

23. Semenza GL: Hypoxia, clonal selection, and the role of HIF-1 in tumor progression. Crit Rev Biochem Mol Biol 35: 71-103, 2000 .
24. Wang GL, Jiang BH, Rue EA and Semenza GL: Hypoxiainducible factor 1 is a basic-helix-loop-helix-PAS heterodimer regulated by cellular $\mathrm{O}_{2}$ tension. Proc Natl Acad Sci USA 92: 5510-5514, 1995

25. Pinlaor S, Sripa B, Ma N, Hiraku Y, Yongvanit P, Wongkham S, Pairojkul C, Bhudhisawasdi V, Oikawa S, Murata M, Semba R and Kawanishi S: Nitrative and oxidative DNA damage in intrahepatic cholangiocarcinoma patients in relation to tumor invasion. World J Gastroenterol 11: 4644-4649, 2005.

26. Surh YJ, Chun KS, Cha HH, Han SS, Keum YS, Park KK and Lee SS: Molecular mechanisms underlying chemopreventive activities of anti-inflammatory phytochemicals: down-regulation of COX-2 and iNOS through suppression of NF- $\mathrm{kB}$ activation. Mutat Res 480-481: 243-268, 2001.

27. Pikarsky E, Porat RM, Stein I, Abramovitch R, Amit S, Kasem S, Gutkovich-Pyest E, Urieli-Shoval S, Galun E and Ben-Neriah Y: $\mathrm{NF}-\kappa \mathrm{B}$ functions as a tumour promoter in inflammationassociated cancer. Nature 431: 461-466, 2004.

28. Loeb LA and Preston BD: Mutagenesis by apurinic/apyrimidinic sites. Annu Rev Genet 20: 201-230, 1986.

29. Wu X, Takenaka K, Sonoda E, Hochegger H, Kawanishi S, Kawamoto T, Takeda S and Yamazoe M: Critical roles for polymerase $\xi$ in cellular tolerance to nitric oxide-induced DNA damage. Cancer Res 66: 748-754, 2006. 